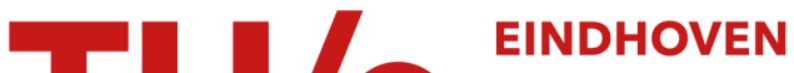 \\ UNIVERSITY OF \\ TECHNOLOGY
}

\section{Teacher educators' collaboration in subject departments}

Citation for published version (APA):

Heldens, H. P. F., Bakx, A. W. E. A., \& den Brok, P. J. (2016). Teacher educators' collaboration in subject departments: collaborative activities and social relations. Educational Research and Evaluation, 21(7-8), 515536. https://doi.org/10.1080/13803611.2016.1153488

DOI:

10.1080/13803611.2016.1153488

Document status and date:

Published: 02/03/2016

\section{Document Version:}

Publisher's PDF, also known as Version of Record (includes final page, issue and volume numbers)

\section{Please check the document version of this publication:}

- A submitted manuscript is the version of the article upon submission and before peer-review. There can be important differences between the submitted version and the official published version of record. People interested in the research are advised to contact the author for the final version of the publication, or visit the $\mathrm{DOI}$ to the publisher's website.

- The final author version and the galley proof are versions of the publication after peer review.

- The final published version features the final layout of the paper including the volume, issue and page numbers.

Link to publication

\section{General rights}

Copyright and moral rights for the publications made accessible in the public portal are retained by the authors and/or other copyright owners and it is a condition of accessing publications that users recognise and abide by the legal requirements associated with these rights.

- Users may download and print one copy of any publication from the public portal for the purpose of private study or research.

- You may not further distribute the material or use it for any profit-making activity or commercial gain

- You may freely distribute the URL identifying the publication in the public portal.

If the publication is distributed under the terms of Article 25fa of the Dutch Copyright Act, indicated by the "Taverne" license above, please follow below link for the End User Agreement:

www.tue.nl/taverne

Take down policy

If you believe that this document breaches copyright please contact us at:

openaccess@tue.nl

providing details and we will investigate your claim. 


\section{Teacher educators' collaboration in subject departments: collaborative activities and social relations}

\section{Henderijn Heldens, Anouke Bakx \& Perry den Brok}

To cite this article: Henderijn Heldens, Anouke Bakx \& Perry den Brok (2015) Teacher educators' collaboration in subject departments: collaborative activities and social relations, Educational Research and Evaluation, 21:7-8, 515-536, DOI: 10.1080/13803611.2016.1153488

To link to this article: http://dx.doi.org/10.1080/13803611.2016.1153488

曲 Published online: 02 Mar 2016.

Submit your article to this journal $₫$

Џll Article views: 158

Q View related articles $₫$

View Crossmark data $\asymp$ 


\title{
Teacher educators' collaboration in subject departments: collaborative activities and social relations
}

\author{
Henderijn Heldens $^{\mathrm{ab} *}$ (D), Anouke Bakx ${ }^{\mathrm{a}}$ (i) and Perry den Brok ${ }^{\mathrm{b}}$ \\ ${ }^{a}$ Fontys Hogeschool Kind \& Educatie, Fontys University of Applied Sciences, Eindhoven, The \\ Netherlands; ${ }^{b}$ Eindhoven School of Education, University of Technology, Eindhoven, The \\ Netherlands
}

(Received 17 February 2015; final version received 4 February 2016)

Teacher educators' collaboration plays an important role in the improvement of teacher education. Many studies in educational research focus on collaboration from 1 particular perspective. A focus on 2 perspectives, a qualitative (focusing on collaborative activities) as well as a quantitative (focusing on relations) perspective, and relating both perspectives, can add to our knowledge. Data were collected in 3 subject departments of a teacher education institute. Findings indicated that educators' collaborative networks inside the departments could gain from more coherent and dense relations, and that key players were important to support and sustain collaboration. Both perspectives were mildly related, correlations were found for "degree" and "information" $(r=.31, p<.05)$, "degree" and "joint work" $(r=.38$, $p<.01)$, and "reciprocity" and "joint work" $(r=.33, p<.05)$, no correlations were found for "degree" or "reciprocity" and "discussing". At the department level, only mathematics showed significant correlations. Results indicated that, in further research, qualitative aspects as well as quantitative aspects should be included.

Keywords: collaboration; teacher educator; interdependence; network theory

\section{Introduction}

During the past decades, research has provided growing support for the assumption that collaboration is an important factor for learning (Eraut, 2004; Horn \& Little, 2010; Levine \& Marcus, 2010; Tynjälä, 2008; Westheimer, 2008). Compared to educators without the social support provided by collaboration, educators involved in collaborative processes are more likely to develop their teaching practice, which, in turn, may produce increases in students' achievements (Goddard, Goddard, \& Tschannen-Moran, 2007). For teacher educators, collaboration is considered equally important as for teachers; next to being a role model in professional collaboration for future teachers, teacher educators' collaboration is considered important for making improvements in teacher education (Caena, 2012). Following the international debate on concerns about the quality of teachers and teacher education itself (Cochran-Smith \& Zeichner, 2005) in recent years, large-scale reforms have been introduced as attempts to improve the quality of teachers and teacher education (DarlingHammond, 2010). In order to succesfully implement such reforms, teacher educators get

\footnotetext{
*Corresponding author. Email: h.heldens@fontys.nl
} 
involved in collaborative efforts to make the required collective changes in their instructional practices (Frank, Zhao, \& Borman, 2004; Goddard et al., 2007; Wenger, 1998). Collaborative processes in teacher education need a sense of urgency or a collective goal in order to develop (Hadar \& Brody, 2010). Unfortunately, and although research on teacher educators' is growing, there is little knowledge on what teacher educator collaboration in the context of educational change actually looks like.

Given this scarcity in the literature on teacher educator collaboration, in the present study, we draw on literature on teacher collaboration, when studying teacher educators' collaboration. Multiple studies on collaboration, especially with regard to teachers (Doppenberg, Bakx, \& Den Brok, 2012; Friend \& Cook, 1992; Horn \& Little, 2010; Little, 1990; Mostert, 1998; Rosenholtz, 1989), use two perspectives on collaboration, (a) a quality-focused perspective and (b) a quantity-focused perspective (Scott \& Carrington, 2011). Research on teacher collaboration using a quality-focused perspective has its roots in the psychological domain and focuses merely on community building via interaction and more specifically on examining types of exchange, such as types of cognitive activities performed by teachers while collaborating or the level of interdependence of these activities (Friend \& Cook, 1992; Kwakman, 2003; Levine \& Marcus, 2010; Little, 1990). Studies on teacher collaboration conducted from the second perspective, the quantitative perspective, provide insights into social structures which support or constrain collaboration and focus merely on the collaborative relations (Coburn \& Russell, 2008; Daly \& Finnigan, 2010; Penuel, Riel, Krause, \& Frank, 2009; Rosenholtz, 1989). This research has its roots in studies in the domain of sociology (Burt, 2000; Scott \& Carrington, 2011).

Although these perspectives might seem somewhat overlapping, each perspective has a different emphasis on collaboration (i.e., an emphasis on the type of exchange versus an emphasis on the number of relations). As a consequence, it has been argued that in research these perspectives should be related in order to develop a fuller understanding of how collaboration actually takes place and enhances learning and learning outcomes (Kreijns, Kirschner, \& Jochems, 2003; Moolenaar, 2012). Also, as has been shown in previous research on collaboration, it is important to focus on subject departments as described by Stodolsky and Grossman (1995). Norms in subject departments can differ from organisational norms, since departments differ in features such as the degree of definition or the number of distinct fields included in the school subject (Stodolsky \& Grossman, 1995). Such differences lead to differences between departments in perceptions on collaboration and, as a result, the actual outcomes of collaboration, such as the implementation of an innovation (Coburn \& Russell, 2008; Penuel et al., 2009; Stodolsky \& Grossman, 1995). In a study by Van Wessum (1997), differences in collaboration were found between (department level) as well as within subject departments (individual level), suggesting that it is important to include both the individual and the department level in research on teacher educator collaboration. Therefore, in this study we address the subject department level as well as the individual level.

Both a qualitative and a quantitative perspective are used to investigate collaboration in the present study. The aim of our study is to describe and to relate these two perspectives on teacher educators' collaboration within their subject departments, as a way to assess teacher educators' collaboration as it actually takes place during educational change. We address the lack of studies including multiple perspectives on collaboration and the need to take more closely into account the specific context of teacher educators within their subject departments. Insights provided by this study might be useful in teacher education for gaining a more comprehensive view of teacher educators' collaboration in the context of 
educational changes taking into account the two perspectives (quality and quantity) and the specific features of collaboration in the departments.

In the following sections, we will first introduce the specific context of this study, before elaborating a bit more on the two perspectives as introduced above. Then, the research questions and methodological approaches are discussed, consisting of (a) quality of the exchange analysis and (b) network analysis (see Instruments section).

\section{Context}

The context for this study is a large-scale educational reform in Dutch teacher education institutes: a nationwide implementation of common goals and standardised tests for (future) primary teachers in all 14 subjects in teacher education (HBO-raad, 2012). This innovation has some resemblance to the Common Core State Standards Initiative in the US (Porter, McMaken, Hwang, \& Yang, 2011), in a way that it involves the introduction of common goals and tests in order to establish concensus on expectations for, in this case, (future) teachers' knowledge and skills. The innovation implies for teacher educators in their subject departments the need to review their courses and possibly adapt the curriculum, for example, by explicating and changing learning goals, lesson materials, or student tests. This implementation therefore implies a collaborative effort of teacher educators in their subject departments. This provides an opportunity to study teacher educators' collaboration within subject departments, but also to look at differences between departments. Teacher educators from one large primary teacher education institution in The Netherlands participated. Teacher educators in the subject departments worked collaboratively at five different locations. The subject departments covered all five locations.

\section{Framework}

Given the gap in the literature on teacher educators' collaboration (see Introduction section), here literature on teacher collaboration is used as a starting point in order to grasp the concept of collaboration and quality and quantity thereof. We assume that, although the contexts and the type of respondents are different in teacher education, the central assumptions and tenets found for teacher collaboration will also hold here.

Tynjälä (2008) found in her review study that teachers learn at work by participating in various working practices, for example, collaborating with colleagues. Collaboration between teachers takes place by interaction (Friend \& Cook, 1992; Little, 2003; Mostert, 1998). For the purpose of this study and in line with previous studies (Friend \& Cook, 1992; Mostert, 1998), teacher educators' collaboration is seen as a form of interaction by which resources like knowledge, information, or experience are exchanged.

\section{The quality-focused perspective}

Many researchers who have studied collaboration in a context of educational change emphasise the quality of the exchange by studying types of collaborative activities or levels of interdependence in these activities (Doppenberg, Bakx, \& Den Brok, 2012; Friend \& Cook, 1992; Horn \& Little, 2010; Kwakman, 2003; Little, 2003; Meirink, Imants, Meijer, \& Verloop, 2010). Most of these studies show that the exchange of experiences is a common activity, whereas collaboration referred to as "joint work" is less common (Kwakman, 2003). These studies point at the importance of interdependence in collaborative activities in order to be effective in terms of learning or making changes in 
Table 1. Categories of collaborative activities (cf. Little, 1990).

Categories of collaborative activities

Examples of each category

1 Story-telling and scanning

2 Aid-and-assistance

3 Sharing

4 Joint work

Venting stories about one's own teaching practice or listening to information

Asking a more experienced colleague for help or advice

Mutual exchange of ideas or opinions, exchange of materials

Collectively developing lesson materials, or evaluating students results

\begin{tabular}{|lrr|}
\hline Story-telling and scanning & Aid and assistance & Sharing \\
\hline & & Joint work \\
\hline Independent & Interdependent \\
\hline
\end{tabular}

Figure 1. Teachers' collaborative activities on a scale of in(ter)dependence (cf. Little, 1990, developed by Doppenberg, Bakx, \& Den Brok, 2012).

practice (Little, 1990, 2002; Meirink, Imants, Meijer, \& Verloop, 2010). In addition, Shank (2006) in her study showed the importance of collaborative activities referred to as "storytelling" for developing a culture of trust and, among other things, to help teachers imagine new possibilities for adapting their courses. These findings illustrate that different types of collaborative activities are important for collaborative learning.

According to Little (1990), collaboration can be placed on a continuum that ranges from independent (working more autonomously) to interdependent (working in a highly collaborative manner). These levels of in(ter)dependence give an idea about the quality of collaboration. In this study, these levels of in(ter)dependence are used to assess teacher educators' collaboration from a qualitative perspective. Little (1990) distinguishes four categories of collaborative activities on a scale of in(ter)dependence. These categories are presented in Table 1.

Following Little (1990), these forms of collaboration constitute more than a simple inventory of activities. They are phenomologically discrete forms that vary from one to another on a dimension of mutual interdependency between the people involved. The category "story-telling" entails low mutual interdependence, whereas "joint work" is an example of collegiality that involves high interdependence (Little, 1990), see also Figure 1. In her study, Little concludes that "the various forms of exchange that pass as collaboration comprise fundamentally different conceptions of professional relations" (1990, p. 531). When people collaborate more intensively, indicated by high levels of interdependence, they contribute more to the implementation of innovations, effectiveness of education, and their collegues' professional development (Little, 2002).

\section{The quantity-focused perspective}

The quantitative perspective adds to a more quality-focused perspective in such a way that the structure of the relations involved in collaboration is taken into account. Social network 
studies on collaboration focus on relations between actors (Borgatti \& Cross, 2003). Following recent literature, networking theory is based on three key assumptions: (a) Resources such as information and knowledge are exchanged in the relationships between individuals; (b) individuals are not independent but interdependent because they are embedded in a social structure; and (c) social networks provide opportunities for, but also constraints on, the actions of individuals and organisations (Scott \& Carrington, 2011).

In a social network, individuals (e.g., teacher educators) are embedded in dyadic relationships (referred to as ties), and dyadic relationships are embedded in larger subgroups of three or more actors that eventually shape a network (Moolenaar, Sleegers, Karsten, \& Daly, 2012). Social network analysis (SNA) provides opportunities to identify the distribution of access to and exchange of resources within teacher educator networks. In the context of educational change, having access to and exchanging resources is important for reaching collective goals and developing an innovative climate (Moolenaar, Daly, \& Sleegers, 2011; Witterholt, Goedhart, \& Suhre, 2015). Studies indicate that having a dense and coherent network supports sustainable innovations (Burt, 1997; Daly, 2010).

SNA is used to study the structure of collaborative relations at the individual level, referred to as the ego level, and at the whole-network level (Hanneman \& Riddle, 2011). Both levels can provide relevant information related to collaboration; therefore both will be briefly discussed.

\section{Whole-network level}

At the whole-network level (i.e., the department level), size and density in the network and connections are important indicators. The size of the network (referred to as degree) is critical for the structure of social relations because of limited resources and capacities that each actor has for building and maintaining ties. The density of a network refers to the number of existing ties in a network in relation to the maximum number of possible ties (Hanneman \& Riddle, 2011). In a dense network, many educators are connected to one another, while in a sparse network, there are only a few relationships among the educators in the network. The density of a network may give insights into phenomena such as the speed at which information diffuses among the educators and the extent to which educators have opportunities for collaborating with others (Hanneman \& Riddle, 2011). The lack of sufficient relationships (ties) can impede or constrain the network's capability to facilitate collaboration and achieve desired goals such as making changes in teaching practice (Daly \& Finnigan, 2010; Hite, Williams, \& Baugh, 2005). Although literature does not agree on what exact amount of relations is desirable, a dense network is considered desirable for facilitating collaboration since dense networks reflect a high level of trust, which, in turn, is an important condition for collaboration (Finnigan \& Daly, 2012). This means that, in order to enhance or sustain teacher educators' collaboration, a network (e.g., in a subject department) benefits from dense relationships.

Where density gives an overall sense of the range of possible social structures, the texture of these connections is what really matters (Hanneman \& Riddle, 2011). In order to gain insight into teacher educators' collaboration and especially the more quantitative aspects thereof, the strength and direction of ties are interesting measures. Strong ties, indicated by, for example, mutual exchange, are important, especially for exchanging complex or tacit knowledge (Krackhardt, 1992). Reciprocity addresses the mutuality of the exchange: If two people indicate that they are connected to one another, a relationship between them is reciprocal. The reciprocity of a teacher educators' network gives an idea of interdependence and stability in the network (Hanneman \& Riddle, 2011). 
Reciprocity is especially of interest when studying collaboration since in a more reciprocal network a deeper exchange of resources, such as tacit knowledge, can be realised (Krackhardt, 1992).

\section{Ego-network level}

Next, collaboration can be studied at the ego level, a bottom-up approach focusing more on individuals and their connections (Hanneman \& Riddle, 2011). "Ego" is an individual "focal" node in a network, for example, an individual teacher educator. An ego network in this study refers to an individual teacher educator (ego) and all colleagues in the subject department he or she collaborates with during the innovation (alters). Several characteristics of ego networks are of interest when studying teacher educators' collaboration. SNA uses centrality to measure the existence or absence of positional advantages of actors (i.e., educators) inside their network. For example, a teacher educator who has many relations has relatively easy access to knowledge of others compared to an educator with only few relations. Centrality refers to an educator's position in a network being central (connected to many others), peripheral (connected to few others), or isolated (not connected at all) (Hanneman \& Riddle, 2011). Centrality is measured by means of an educator's degree (number of relations) or by means of betweenness. Degree centrality captures an educator's immediate ties (relations) to an alter. Multiple studies have found evidence that homophily, "the principle that a contact between similar people occurs at a higher rate than (between) dissimilar people", plays an important role (McPherson, Smith-Lovin, \& Cook, 2001, p. 416). In schools, homophily often expresses itself as educators reaching out to colleagues with similar structural positions in the network, for example, teacher educators that collaborate more with colleagues teaching the same grade or same course (Coburn, Choi, \& Mata, 2010). Another strong predictor of tie formation (building relations) is proximity. Proximity is the physical distance separating educators in the school organisation, for example, working in physical distant classrooms (Coburn et al., 2010). Betweenness measures both the direct and indirect ties between an educator and others in the subject department (Hanneman \& Riddle, 2011). For example, when Teacher A collaborates with Teacher $\mathrm{B}$, this is referred to as a direct relation. When Teacher $\mathrm{C}$ collaborates with Teacher B but not with Teacher A (e.g., because Teachers B and C both teach the same course and Teacher A teaches a different course), the relation between Teachers $\mathrm{A}$ and $\mathrm{C}$ is indirect (namely, through Teacher B). Educators with a high in-degree or betweenness play an important role in sharing knowledge or information in a collaborative network, since they are apparently considered as a source of knowledge or information by others. These educators are central in the network.

\section{Key players}

Actors with relatively high scores on degree and betweenness in a network are more central than others and can be considered as key players in collaboration (Borgatti, 2006). These key players, being more connected than others, have more opportunities to collaborate (Granovetter, 1982). Having a favoured (i.e., central) position in the network means that an educator may have better bargains in exchange, a greater influence, and may be a focus for defence and attention from those in less favoured positions (Hanneman \& 
Riddle, 2011). These educators having a favoured position in the network are often referred to as key players (Borgatti, 2006; Spillane, 2005). With regard to developing and sustaining collaboration, key players are important, since they are in a position to connect otherwise not connected educators in less favoured positions (Gould \& Fernandez, 1989). An interesting question is whether or not functional positions (such as chair of the department) match with key players. We assume that there will be some mismatch, since informal leaders might play a role in collaboration in the context of the implementation of an innovation next to the more formal leaders (Moolenaar et al., 2011; Spillane, Halverson, \& Diamond, 2004).

\section{Differences between subject departments}

Recent studies on teacher collaboration show large differences in collaboration between schools or departments or (sub)teams, due to different features like the degree of definition or the number of distinct fields included in the school subject, the degree of sequence, the subject matter being perceived as being static or dynamic, and the required or elective status of the subject (De Lima, 2007; Siskin, 1994; Stodolsky \& Grossman, 1995; Van Wessum, 1997). Studies also show variety in network measures among and within schools, such as among subject departments (Coburn et al., 2010; De Lima, 2007; Frank et al., 2004; Moolenaar et al., 2012; Siskin, 1994). In previous studies on collaboration, it has been argued that it is important to focus on differences between subgroups, such as departments, while studying collaboration, since subgroups might develop norms that differ from the school culture, which in turn might affect perceptions on collaboration (Coburn \& Russell, 2008; Penuel et al., 2009) and as such the actual results of collaboration, such as the implementation of an innovation. In order for teacher education to adaptively support their teacher educators' collaboration inside the departments, it is important to study the nature of differences in collaboration at the subject department level.

\section{Research questions}

The national implementation of common goals and tests in teacher education programmes provides the context for studying teacher educators' collaboration in subject departments. Teacher educators' collaboration is studied by using a qualitative perspective, focusing on collaborative activities, as well as a quantitative perspective, focusing on collaborative relations, both at the individual (ego) and at the collective (department) level.

This leads to the following main research question:

(RQ) How are the quality and quantity of teacher educators' collaboration related?

In order to answer the main question, the following subquestions are stated:

(RQ 1.1) How can the quality of teacher educators' collaborative activities during innovation be described, in terms of "story-telling and scanning", "aid and assistance", "sharing", and "joint work", both at the individual and at the aggregated (department) level?

(RQ 1.2) How can the quantity of teacher educators' collaborative relations be described, both at the individual level in terms of degree, betweenness, and key players and at the network (department) level in terms of density, centrality, and reciprocity? 
Table 2. Participating teacher educators per department.

\begin{tabular}{lccc}
\hline Department & $\begin{array}{c}\text { Number of } \\
\text { participants }\end{array}$ & $\begin{array}{c}\text { Years of experience in } \\
\text { education } \\
\text { Mean }\end{array}$ & $\begin{array}{c}\text { Years of experience as } \\
\text { teacher educator } \\
\text { Mean }\end{array}$ \\
\hline Mathematics & 16 & 20.6 & 8.5 \\
Dutch language & 14 & 21.6 & 9.0 \\
Environmental science & 21 & 24.0 & 14.3 \\
Total number of participants & 51 & 22.5 & 11.3 \\
\hline
\end{tabular}

\section{Method}

\section{Procedure and participants}

This study was performed in a large primary teacher education institution in The Netherlands. In The Netherlands, teacher education for both primary and secondary school teachers takes place in higher education institutes. In universities of applied science, a 4year trajectory leads to a bachelor degree in primary or secondary education. The particular institute in this study is organised in five different locations and employs 150 teacher educators. Each location is reponsible for the education of a group of future teachers, including guidance of workplace learning and assessments. Teams vary in size, ranging from 8 to 46 teacher educators. Subject departments ${ }^{1}$ are responsible for the development and implementation of the curricula. The institute's curriculum consists of 14 different subjects, with pedagogy, Dutch language, and mathematics as the main subject areas. All 60 teacher educators in three subject departments, (a) mathematics, (b) Dutch language, and (c) environmental science, were included in this study. Mathematics and Dutch language were chosen because they are core subjects in Dutch primary school curricula and are tested in a national knowledge test. Environmental studies was chosen because of the Dutch government's emphasis on better preparation of children for a career in science (Programmaraad Verbreding Techniek Basisonderwijs, 2004).

Of the 60 invited teacher educators, 51 agreed to participate in this study (a response rate of $85 \%$ ). Of these, $57 \%$ were male. The age of the teacher educators varied between 31 and 64 years old $(M=48.5 ; S D=9.2)$. Years of experience in teacher education varied between 1 and 35 years $(M=11.0 ; S D=8.2)$. Table 2 presents the number of participants for each department and some background characteristics.

To measure interdependence, a survey was used for collecting data on the collaborative activities. Although it is common to study interdependence using qualitative methods, given the large group of respondents a survey was deemed more feasible. Moreover, such an approach has been successfully used before in student interdependence studies (Blaney, Stephan, Rosenfield, Aronson, \& Sikes, 1977). To measure the networks, a network survey was used, as is common in network research (Scott \& Carrington, 2011).

All 51 participants completed the two questionnaires during a teacher educator meeting where two researchers were present to assist the data collection process. Teacher educators completed the questionnaires individually and anonymously. Before completing the questionnaires, the participants were informed about the nature and goals of this study.

\section{Instruments}

First, in order to map and categorise the collaborative activities of teacher educators, an interdependence questionnaire was developed consisting of 30 items, based on Little's 
four levels of interdependence (Little, 1990) and one open question for adding collaborative activities that were not covered by the 30 items. For each of Little's (1990) four categories for teacher collaboration, items were constructed by the researchers. Respondents were asked to indicate the frequency of a certain activity that was mentioned in the item, using a 5-point Likert scale varying from 1 (never) to 5 (very often). An exploratory factor analysis ${ }^{2}$ was conducted to investigate construct validity of the questionnaire. This analysis revealed three underlying factors (instead of Little's [1990] four categories), explaining $67.6 \%$ of the total variance with an eigenvalue above 1.0. Factor loadings suggested that these factors could be labelled as: (a) "joint work"; (b) "exchange of information and exchanging experience", referred to as "information and experience"; and (c) "discussing work": Cronbach's alpha for the resulting scales varied from 0.92 to 0.94 . The constructed scales differed somewhat from the four categories used by Little. Little's categories "story-telling" and "aid" refer to exchanges with a low level of interdependence; the category "information and experience" in our study also refers to exchange with a low level of interdependence, but - as factor analysis showed - could not be seen as two different categories. Our scales "discussing work" and "joint work" show some resemblance with Little's categories "sharing" and "joint work", although "discussing work" more explicitly refers to sharing ideas regarding points of view, whereas Little's "sharing" also refers to sharing student outcomes.

Pearson correlation coefficients were calculated in order to investigate overlap between the three scales. Correlations between scales were high. The scales "joint work" and "information and experience" correlated 0.70 ; the scales "joint work" and "discussing work" 0.72 ; the scales "information and experience" and "discussing work" 0.70 . Table 3 presents the scales, descriptions, and item examples.

Second, to map teacher educators' collaborative networks whole network data were collected by means of an open-ended questionnaire in which respondents were asked to report with whom they shared a particular relation regarding collaboration on the innovation

Table 3. Scales of the interdependence instrument, reliability, number of items, description, and item examples.

\begin{tabular}{|c|c|c|c|c|c|}
\hline Scale and reliability & $\begin{array}{l}\text { Number } \\
\text { of items }\end{array}$ & Description & Item example & Mean & $S D$ \\
\hline Joint work $(\alpha=0.94)$ & 13 & $\begin{array}{l}\text { Joint evaluation of the } \\
\text { programme and } \\
\text { making adaptations on } \\
\text { methods, lessons, } \\
\text { tests, etc. }\end{array}$ & $\begin{array}{l}\text { Adaptation of } \\
\text { didactic } \\
\text { approach }\end{array}$ & 2.92 & 1.02 \\
\hline $\begin{array}{l}\text { Information and } \\
\quad \text { experience }(\alpha=0.94)\end{array}$ & 10 & $\begin{array}{l}\text { Seeking information or } \\
\text { giving information to } \\
\text { colleagues and sharing } \\
\text { experiences of asking } \\
\text { questions concerning } \\
\text { the knowledge base }\end{array}$ & $\begin{array}{l}\text { Listening to } \\
\text { information } \\
\text { of a } \\
\text { colleague }\end{array}$ & 3.42 & 0.96 \\
\hline Discussing work $(\alpha=0.92)$ & 7 & $\begin{array}{l}\text { Discussing the } \\
\text { knowledge bases, the } \\
\text { presentation of } \\
\text { knowledge in the } \\
\text { curriculum, discussing } \\
\text { student goals, and } \\
\text { tuning on teaching and } \\
\text { guiding students }\end{array}$ & $\begin{array}{l}\text { Discussing the } \\
\text { way to teach } \\
\text { knowledge }\end{array}$ & 3.38 & 0.98 \\
\hline
\end{tabular}


within the subject department. Background characteristics were used from the first questionnaire on collaborative activities. Three types of collaborative relations were included in the social network questions: (a) joint work, (b) seeking information, and (c) asking for advice. These three types of exchange are considered relevant for studying collaboration within networks and were used in other recent network studies as well (Daly, 2010; Moolenaar, 2012). Table 4 presents an overview of the social network questions to assess these types of exchange within the social networks of teacher educators. Joint work refers to work that teacher educators employ (while implementing the national knowledge standards) in collaboration (Little, 1990). Seeking information refers to social relationships for acquiring information (Granovetter, 1982; Wenger, 1998) and refers to Little's (1990) category of story-telling. Asking for advice resembles Little's (1990) category of aid and assistance and is of interest since receiving advice may be part of an on-going development and may facilitate the adoption and implementation of reform and innovation in institutions (Moolenaar et al., 2011).

In order to assess to what extent the three networks of a subject department were related, a test to reveal statistically significant correlation scores between relations in different networks was performed ${ }^{3}$ (Hanneman $\&$ Riddle, 2011). Results on the networks at the department level were aggregated to obtain an overall picture of the relations between the networks (information, joint work, advice). In general, all three subject department networks were weakly to moderately correlated. Correlation coefficients were: information - joint work: $r=.47$; advice - joint work: $r=.36$; and information - advice: $r=.43$. These findings suggest that all networks measured different facets of teacher educators' collaboration, and none of the networks showed extensive similarity with other networks.

To elicit reliable network information, we used a name generator technique described by De Lima (2010) to measure the network relations: Respondents of each department were asked to indicate the people with whom they had established a specific kind of relationship by free recall. The total number of relationships a respondent could elicit was free of choice but was restricted to actors within the department in order to get a complete image of each department's collaborative networks. Additionally, to measure the strength of relationships, ratings varying from 1 (occurred only once) to 5 (occurred every week) were used.

Third, in order to characterise the network structure at both the ego level and the wholenetwork level, network measures, for example, network density ${ }^{4}$, were calculated using UCINET, specialised software to analyse network data (Borgatti, Everett, \& Freeman, 2002). Network descriptive measures were calculated both at the ego level (individual) and at the network level (subject department).

At the individual level, the following variables were established. The degree was measured by scores on in-degree and out-degree and betweenness. In-degree was calculated by numbering teacher educators by whom the respondent was nominated. Out-degree was calculated by numbering the teacher educators the respondent had nominated. Also,

Table 4. Social network questions to assess teacher educators' networks.

\begin{tabular}{ll}
\hline Scale & \multicolumn{1}{c}{ Question (translated in English) } \\
\hline $\begin{array}{l}\text { Information } \\
\text { Joint work }\end{array}$ & $\begin{array}{l}\text { If I need information on the national knowledge base of my subject domain I turn to: } \\
\text { turn to: }\end{array}$ \\
$\begin{array}{l}\text { Advice } \\
\text { If I need advice concerning the implementation of the national knowledge base in my } \\
\text { subject domain I turn to: }\end{array}$ \\
\hline
\end{tabular}


normalised scores were calculated as a percentage of the relationships of the whole network. Standard deviations for in- and out-degree and also for the normalised scores were calculated.

Betweenness was measured by locating the shortest paths between all pairs of actors, and counting up how frequently each actor fell in each of these pathways (Freeman's betweenness; cf. Borgatti et al., 2002). The proportion of times that actors were "between" other actors for the sending of information was added for each actor to get a measure of actor centrality. This measure was normalised by expressing it as a percentage of the maximum possible betweenness that an actor could have had (Hanneman \& Riddle, 2011). In order to calculate the individual measures, the department network data were aggregated into one large network.

At the subject department level, referred to as the network level, the network was defined through the measures density, centralisation, and reciprocity. The density of a network was measured by dividing the total number of ties that individuals report by the total number of possible ties. The networks' centralisation was captured by the proportion of possible ties with others that were realised (reported in the survey). Scores ranged from 0 (no variability - all members of the network are chosen for information as frequently) to 1 (maximum variability - most educators in a network only nominate a single person in the network, while these teacher educators themselves are not nominated at all).

Reciprocity was calculated as the number of reciprocal relationships in a department, divided by the total possible number of reciprocal relationships. The reciprocity of a teacher educators' network may range from 0 (none of the relationships in the network are reciprocated or mutual) to 1 (all of the relationships in the network are reciprocated or mutual).

\section{Analysis}

To characterise collaborative activities and network structure (subquestions RQ 1.1 and RQ 1.2), descriptives means and standard deviations were calculated. To answer the first and second subquestions, referring to differences between subject departments, analyses of variance (ANOVA) were conducted, with collaborative activities (scales) and network attributes as the dependent variables and department (network) as the independent variable. Possible differences in network size between the three departments must be considered since size is critical for the structure (Hanneman \& Riddle, 2011). Normalised scores are used to reduce the effects of difference in size.

Key players in the department networks were identified by calculating centrality measures per ego, using degree centrality and Freeman's betweenness centrality in UCINET (subquestion RQ 1.2). To find out if any relationship existed between the qualitative perspective and the quantitative perspective (RQ), scores of variables of both perspectives at the individual level were correlated using Pearson's correlation coefficient.

\section{Results}

\section{The quality of teacher educators' collaborative activities}

To assess the quality of the collaborative activities, as reported by teacher educators, on a scale of interdependence (RQ 1.1), mean frequency scores on each of the three scales, as derived from the questionnaire, were compared. Mean scores on the activity scales varied from 3.42 ("information and experiences" and "discussing work") to 2.92 ("joint 
Table 5. Scale scores per department.

\begin{tabular}{llccc}
\hline Scale & \multicolumn{1}{c}{ Department } & Mean (range 1-5) & $S D$ & $F(p)$ \\
\hline 1 Joint work & & 2.9 & 1.02 & $5.8(0.06)$ \\
& Mathematics & 3.2 & 1.23 & \\
& Dutch language & 3.4 & 0.59 & \\
2 Information and experiences & Environmental sciences & 2.3 & 0.76 & \\
& & 3.4 & 0.96 & $0.8(0.77)$ \\
& Mathematics & 3.3 & 1.15 & \\
& Dutch language & 3.7 & 0.73 & \\
3 Discussing work & Environmental sciences & 3.3 & 0.97 & \\
& Mathematics & 3.4 & 0.98 & 0.2 \\
& Dutch language & 3.5 & 1.09 & $(0.81)$ \\
& Environmental sciences & 3.5 & 0.84 & \\
\hline
\end{tabular}

work") on a scale from 1 to 5. Thus, collaborative activities with a low to medium level of interdependence occurred reasonably often, while highly interdependent activities (i.e., joint work) were perceived to a slightly lesser degree.

The ANOVA that was performed to find possible relations between interdependence and belonging to a specific subject department showed that belonging to a specific subject department explained the variance for the scale "joint work" $(F=5.8)$ with a significance of $p=0.06$. Table 5 shows means and standard deviations per scale at the department level. While most differences between departments were not statistically significant, when looking at the standard deviation, it appeared that within the Dutch language department perceptions differed least, while differences in perceptions were largest for the mathematics department, meaning that mathematics teacher educators seemed to differ most from one another in the way they perceived their collaborative activities. Dutch language appeared to have the highest scores on each of the three scales, meaning that educators in this department perceived to collaborate more frequently, followed by the mathematics department and the environmental science department, with slightly lower scores.

\section{The quantity of teacher educators' collaborative relations}

With regard to teacher educators' collaborative relations at both the ego level and the whole-network level (RQ 1.2), results showed variation, both between individual teacher educators and between subject departments.

Table 6. Individual-level network descriptives: degree and betweenness.

\begin{tabular}{lllllllll}
\hline & \multicolumn{3}{c}{ In- and Out-degree } & & \multicolumn{2}{c}{ Betweenness } \\
\cline { 2 - 3 } Network & $M$ & $S D / \mathrm{In}^{*}$ & $S D /$ Out* & Max** & Min** & & $M$ & $S D$ \\
\hline Information & 2.0 & 1.6 & 2.4 & 8.0 & 0.0 & & 7.2 & 16.7 \\
Joint Work & 1.8 & 2.1 & 2.8 & 16.0 & 0.0 & & 5.9 & 14.3 \\
Advice & 1.7 & 1.7 & 2.9 & 14.0 & 0.0 & & 4.3 & 12.3 \\
\hline
\end{tabular}

* SD/In refers to the standard deviation of all incoming relationships; $S D$ /Out refers to al outgoing relationships;

**Max refers to maximum values; Min refers to minimum values. 
At the ego-network level, results on degree and betweenness, as calculated in UCINET, are presented in Table 6, with descriptive statistics for each of the three networks, "information", "joint work", and "advice". Mean scores on degree varied only little between the three networks, meaning that, on average, teacher educators used only slightly more relations in the information network compared to their joint work and advice networks. The QAP procedure (see Instruments section) showed that these different networks only partially overlapped. Standard deviations showed differences between actors (see Table 6), meaning that educators differed in their network sizes. Some educators even showed a minimum score of zero relations (see Table 6), indicating that they were not participating at all in the collaborative network. The ANOVA, used to assess the variance in degree between individual educators, indicated that belonging to a specific subject department explained the variance in degree $\left(F_{\text {outdegree }}=4.3 ; F_{\text {indegree }}=5.8\right)$, with a significance of $p=0.02$ for out-degree and $p=0.007$ for in-degree. A comparable pattern as for degree was found for betweenness, with the "information" network as the most centralised. The mean number of times that an actor was found "between" other actors for exchanging information was 7.2.

Regarding the key players, the standard deviation for betweenness showed differences between educators (see Table 6), indicating that some educators were more central in their collaborative networks than others. These central educators are referred to as key players in the collaborative networks. A striking result was that the key players in each of the departments were located in one and the same location. This is an interesting result since it points at differences between locations in their conditions for collaboration. This result was not found for betweenness centrality. Some of the key players occupied functional leading positions (chair of the department network), but this did not apply to all central actors, meaning that not only formal leaders are key players in the collaborative network. Key players differed in age and years of experience.

Results at the network level (subject department) are presented in Table 7, with descriptive statistics for the three network questions in each of the three departments.

At the network level, results showed an overall density that varied between .05 and .49 , indicating that most networks were not very coherent (see Table 7), since the maximum density is 1.0 when everyone is connected to everyone else. Taking the size of the networks into account, a density of .49 is reasonably dense and .05 is not dense at all.

Table 7. Network level descriptive statistics: density, centralisation, and reciprocity.

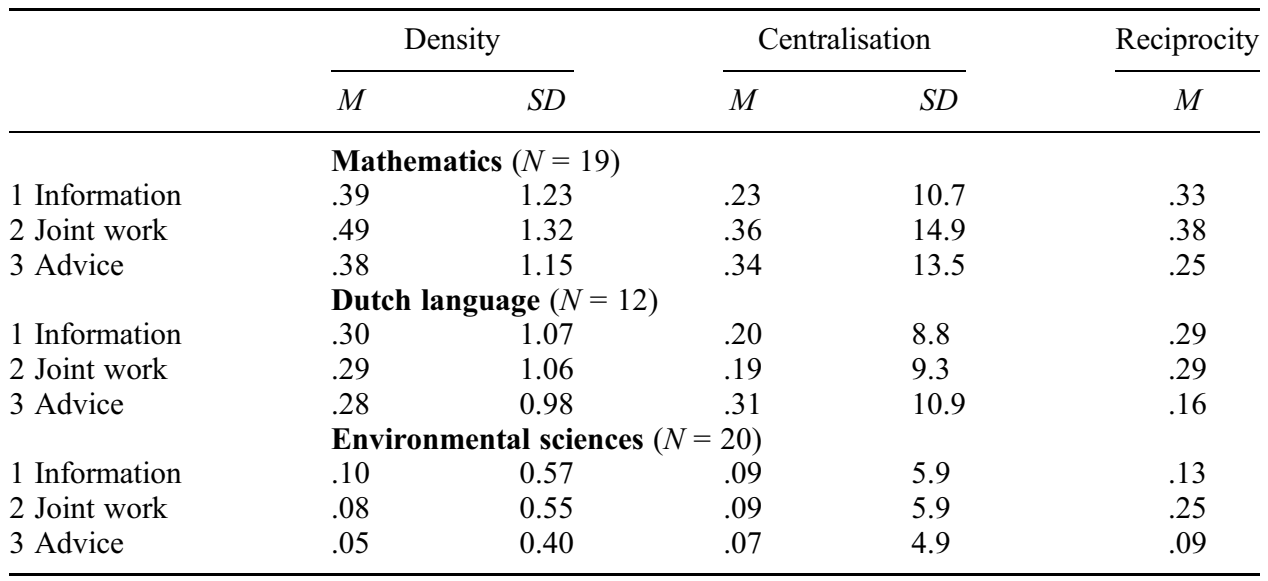


Variation between the departments in density was found. Standard deviations in the mathematics department were relatively high (see Table 7), indicating that there was much variation between teacher educators within the department in the number of relationships they had. Results indicated that the networks of teacher educators in the mathematics department had the highest density $(.39, .49$, and .38 , respectively), with the "joint work" network the most dense: Of all possible relationships in the department, $49 \%$ were formed around "joint work". Teacher educators in the environmental science department had the lowest network density. In their advice network, only $5 \%$ of all possible relationships in the department were formed. The Dutch language department showed network density levels slightly below the levels seen in the mathematics department. Department-level centralisation findings suggested that the networks were least centralised in the environmental science department and most centralised in the mathematics department. This means that in the environmental science department, relationships were more evenly distributed among teacher educators, whereas in the mathematics and Dutch language department, relationships were more centred on a few teacher educators. Findings for reciprocity reflected more or less the same pattern as found for the centralisation and density measures, with higher levels of reciprocity in the mathematics department and lower levels in the environmental science department. These findings indicate that in the collaboration network $40 \%$ of all relationships in the mathematics department were reciprocal, but this was only $21 \%$ in the environmental science department.

\section{Relations between the quality and quantity of collaboration}

Regarding the relation of both perspectives (RQ), Pearson's correlations coefficients are presented in Table 8. Results showed a statistically significant positive correlation between ego-network descriptives degree and reciprocity and each of the teacher educator collaborative activities "information" and "joint work", indicating that on an aggregated level the number of relationships as well as the direction of the relationships contributed to the frequency of activities employed, with a medium effect size (ranging from $31 \%$ to $47 \%$ explained variance). This was also the case for in-degree in relation to the activity

Table 8. Correlations between networking aspects and activity-related aspects.

\begin{tabular}{|c|c|c|c|c|}
\hline & & Information & Joint work & Discussing \\
\hline \multirow[t]{3}{*}{ Overall } & NrmOutdegree $^{1}$ & $.31 *$ & $.47 * *$ & .17 \\
\hline & NrmIndegree $^{2}$ & $.36 *$ & $.45^{* *}$ & $.29 *$ \\
\hline & Reciprocity & $.38 *$ & $.33 *$ & .18 \\
\hline \multicolumn{5}{|l|}{ Department } \\
\hline \multirow{3}{*}{$\begin{array}{l}\text { Mathematics } \\
\text { network }\end{array}$} & NrmOutdegree & $.66^{* *}$ & .43 & .30 \\
\hline & NrmIndegree & $.55 *$ & $.69 * *$ & $.70 * *$ \\
\hline & Reciprocity & $.59 *$ & $.65^{* *}$ & .39 \\
\hline \multirow{3}{*}{$\begin{array}{l}\text { Dutch language } \\
\text { network }\end{array}$} & NrmOutdegree & -.21 & -.26 & -.05 \\
\hline & NrmIndegree & .18 & .37 & -.41 \\
\hline & Reciprocity & .57 & -.54 & .05 \\
\hline \multirow{3}{*}{$\begin{array}{l}\text { Environmental } \\
\text { science network }\end{array}$} & NrmOutdegree & .22 & $.50 *$ & .11 \\
\hline & NrmIndegree & .07 & -.28 & -.04 \\
\hline & Reciprocity & .29 & .02 & .09 \\
\hline
\end{tabular}

${ }^{1} \mathrm{NrmOutdegree}$ refers to the normalised scores on Outdegree; ${ }^{2} \mathrm{NrmIndegree} \mathrm{refers} \mathrm{to} \mathrm{the} \mathrm{normalised} \mathrm{scores} \mathrm{on}$ Indegree; **Correlation is significant at the 0.01 level (2-tailed); ${ }^{*}$ Correlation is significant at the 0.05 level (2tailed). 
"discussing", although the effect size was somewhat smaller ( $29 \%$ of explained variance). However, no statistically significant relations were found between out-degree and reciprocity and the activity "discussing". At the department level, statistically significant correlations were only found in the mathematics department and in one case in the environmental science department. In the Dutch language department, negative correlations were found between out-degree and teacher activities, indicating that having more outgoing relationships diminished the number of activities; however, these correlations were not statistically significant, and the effect sizes were rather small.

\section{Conclusion and discussion}

This study investigated teacher educators' interactions while working collaboratively, using a qualitative and quantitative perspective. The aim of the study was to describe and to relate these two perspectives on teacher educators' collaboration inside their subject departments, to assess teacher educators' collaboration as it actually takes place during educational change. In the next subsections, we will discuss the most important findings regarding each of the research questions.

\section{The quality of collaboration and variance per department}

Different from Little's (1990) four forms of collaborative activities, three different forms of collaborative activities of teacher educators could be distinguished in our data: "joint work", "exchanging information and experiences", and "discussing work". Teacher educators reported forms of collegiality with low levels of interdependence (such as exchanging information) relatively more often compared to activities with a high level of interdependence. This finding was also reported in previous studies on teacher collaboration (Bakkenes, Vermunt, \& Wubbels, 2010; Doppenberg, Bakx, \& Den Brok, 2012; Doppenberg, Den Brok, \& Bakx, 2012; Kwakman, 2003; Van Wessum, 1997). This indicates that teacher educator collaboration, as was assumed in our framework, can be compared to teacher collaboration with regard to the quality of the collaborative activities during educational change. Given the differences found between the three subject departments, our findings can add to the discussion regarding the meaning or nature of these differences. It appeared that teacher educators working within the environmental science department reported working collaboratively less often than teacher educators within the other two departments. This can be seen in relation to the implementation of a new teaching method, in which the specific content of the subject matter appears to matter (Deng, 2007; Grossman \& Richert, 1988; Shulman, 1986). In line with our findings in the underlying study, Stodolsky and Grossman (1995) reported more collaboration within departments that are well defined, static, and sequential in nature, such as mathematics, compared to subjects without these features, such as English language and science. On the other hand, Witziers, Sleegers, and Imants (1999) reported that English teachers were more willing to collaborate with colleagues within the department than teachers in math or environmental science departments. In line with our own findings, De Lima (2007) reported on differences in interaction between departments, such as density and centrality, in his study of two anonymous departments (A and B) in secondary education. Given the differences that were found in all of these studies, evidence is accumulating that collaboration differs per department due to their specific features. This implies that for supporting collaboration a different approach per department might be required, for example, focusing on norms regarding collaboration both within the department and across departments 
(Coburn \& Russell, 2008). More study is needed to further define these differences and find adaptive approaches that support collaboration as it presents itself within the departments.

\section{The quantity of collaboration and variation per department}

Results for teacher educators' relations were studied at the network level (department) and at the ego level (individual teacher educators). An overall trend in the results for the second subquestion (RQ 1.2) was the difference between the collaborative networks (i.e., information, advice, and joint work network), as shown by the results of the QAP test. This is an interesting result because it indicates that teacher educators interact with different colleagues for different purposes. This finding was also reported in studies of teacher networks (Daly, 2010b13; Moolenaar, 2012) and indicates that, in order to get a complete picture of teacher educators' collaboration, it is important to ask different network questions.

With regard to the network characteristics (degree and betweenness at the ego level and density, centrality, and reciprocity at the network level) in general, results indicated low to medium coherence in the networks. This indicates that conditions for collaboration, such as a dense and coherent network with strong ties between educators, as described in network studies (Finnigan \& Daly, 2012; Krackhardt, 1992), were not fully met. Since trust and proximity are considered important conditions for forming relations (Daly, 2010), our results might imply that for teacher education institutes it is important to do more to build trust inside the departments and make improvements with regard to proximity in order to increase collaboration.

\section{Key players in the networks}

Network results indicated that some teacher educators occupied a more central position than others within their department, which might indicate them as key players (Atteberry \& Bryk, 2010; Ferligoj, Doreian, \& Batagelj, 2011). Two findings were of special interest in this respect. First, although one might expect that the central positions were occupied by educators with a formal structural position, such as department leaders, this was not always the case. Apparently, others than formal leaders are central to the network. This is an interesting result from a more organisational perspective, because leadership might be distributed among teacher educators, instead of being concentrated in formal leadership positions (Spillane, 2005). It also means that teacher educators in formal roles do not always enact their intended advisory role (Coburn \& Russell, 2008; Moolenaar et al., 2011; Penuel, Frank, \& Krause, 2010).

Second, all key players were located in one and the same location, of five locations of the teacher education institute. This might indicate that, next to departments, locations differed in their conditions for forming relations, and, as a result, for collaboration. Further research is needed to gain more insight into a possible relation between location characteristics and centrality of individuals.

With regard to differences between departments, again, some interesting findings became clear, indicating that collaboration is perceived differently by different departments. The mathematics department differed from the other departments with respect to density and centrality. The collaborative relations in this department were more coherent, meaning that resources were exchanged more easily and more members were involved in the collaborative process, with positive implications for sustaining innovation (Moolenaar et al., 2011). Possibly, this occurred as a result of their history in collaboration in national and regional mathematics networks (e.g., WC-bel, a former regional mathematics 
network in the south of The Netherlands, and Panama, a national mathematics conference), but also aspects like a well-defined subject content (Stodolsky \& Grossman, 1995) or department culture (De Lima, 2007; Siskin, 1994) may play a role in this coherence.

\section{Relations between the quality and quantity of teacher educators' collaboration}

Results showed few relations between activity-related aspects (interdependency) and networking aspects (degree, reciprocity), except for the mathematics department, where associations were found between all three forms of collaboration and degree. Especially the association of high interdependent collaborative activities like "joint work" with reciprocity and degree in this department were relatively strong and statistically significant at the 0.01 level. Given the absence of further statistically significant relations between the two perspectives in the other networks, this is an interesting result. It means that it important to include both perspectives in further study of teacher educators' collaboration. Also, by relating both perspectives a more comprehensive view on teacher educators' collaboration can be obtained. For example, as was shown in this study, collaboration among teacher educators can gain not only from enhancing the quality of collaborative activities in general or "joint work" activities in particular, but also from forming more relations inside the departments, especially in the environmental science domain, and from developing the strength of ties.

\section{Limitations}

Like all research, this study had its limitations. In this baseline study, we focused on teacher educators of specific subject domains within five different locations of one primary teacher education institute. Due to the level of analysis, the response group for each of the subject departments was relatively small. Therefore, caution is needed in generalising results. Additionally, in future research, a more qualitative investigation of interdependencerelated and networking aspects of teacher educators' collaboration may provide a deeper understanding of teacher educators' collaboration.

Although several techniques were used to explore teacher educators' interactions, another limitation is that data were collected at one single moment. A longitudinal design would open possibilities to follow the participants during a longer period of time, while passing through several phases within the innovation. Since the implementation of the national knowledge bases can be considered a large-scale educational innovation, it may be assumed that over time, changes in interactions and collaboration might occur.

\section{Implications}

The results of this study might be useful when aiming at enhancing the quality and quantity of teacher educators' collaboration during educational change. Increasing awareness among teacher educators regarding their own collaborative behaviour in terms of quality and quantity might be an important first step. Results of this study can be used by teacher educators or administrators to reflect on quality and quantity of their collaboration and to set goals for further developing collaboration within the departments. Such goals should be related to both qualitative and quantitative aspects, for example, encouraging teacher educators' "joint work" collaborative activities inside the department to increase interdependence in the relationships. Also, supporting exchange of experiences and successes related to the innovation (story-telling) as a means to build trust might help to develop forming 
relationships and increase interdependence in the relations. Next, improving accessibility or reachability of teacher educators, for example, by using digital communication tools or aligning educators' lesson schedules across locations can be used as a means to support educators in forming and maintaining relations despite geographical distance. For reaching such goals, this also involves a critical review and prioritising of all department activities. The findings regarding key players imply that acknowledging and supporting informal leaders within the department in their role might help sustaining and increasing coherence in the networks. Finally, in order to prevent undesirable differences in implementation, it might help departments to regularly tune their approach with one another.

For further study of teacher educator collaboration, the results imply a need for using the two perspectives on collaboration, since each perspective provides its own unique insights. It might be interesting to investigate how these perspectives, being unique or (partly) overlapping can explain collaboration or possible changes in collaboration. To confirm our results, it is important to repeat this study in other (international) teacher education institutes.

\section{Notes}

1. Subject departments in teacher education involved in this study differ from subject departments in secondary education in that they cover more than one location.

2. "Factor analysis is any of several methods by which the researcher attempts to relate the calculated factors to theoretical entities (scales). This is done differently depending upon whether the factors are believed to be correlated (oblique) or uncorrelated (orthogonal)" (Vogt, 1993, p. 91). In this study, Oblimin rotation was used since factors were believed oblique.

3. In SNA, this test is referred to as the Quadratic Assignment Procedure (QAP).

4. In this study, strategies of extracting both ego-network and whole-network characteristics were used (Hanneman \& Riddle, 2011). First, matrices were constructed for each network question, for each subject domain separately. Every matrix was built in the same way: If a Teacher educator i nominated Teacher educator $\mathrm{j}$ as a relationship, 1 was entered in the matrix cell Xij. If Teacher educator i did not indicate a relationship with Teacher educator $\mathrm{j}, 0$ was entered in cell Xij. The procedure resulted in asymmetric matrices for every subject department for every network question asked, summarising all direct relationships among teacher educators. In order to analyse the networks, networks were made symmetrical by including only subject department members in the matrices. These matrices were necessary to calculate possible relations with actor characteristics.

\section{Notes on contributors}

Henderijn Heldens studied Human Geography at Utrecht University in The Netherlands and graduated as a teacher at UNILO Institute of Education (Radboud University, Nijmegen). Since 2012, she has combined her work as a teacher educator with studying as a $\mathrm{PhD}$ student at Eindhoven School of Education. Her research project aims at developing a more comprehensive view of teacher educators' learning in collaborative networks. Henderijn started working as a teacher educator in 1997 at Katholieke Pabo Sittard, The Netherlands. Since over 15 years, she has worked at Fontys University of applied sciences as a teacher educator. Currently, Henderijn teaches in two masters: "Master Leadership in Education" and "Master Leren en Innoveren" at Fontys University of applied sciences in Eindhoven, The Netherlands. Her main areas of expertise as a teacher educator are practice-based research, social context of education, and teacher professional development.

Anouke Bakx is a senior researcher and lecturer "Leren en Innoveren" at Fontys University of applied sciences, Fontys Child Studies and Education. As a lecturer, Anouke leads practice-based research projects merely focusing on teaching in primary education. She has her roots in primary education and studied educational psychology. In 2001, she completed her $\mathrm{PhD}$ entitled "Acquisition, development and assessment of social communicative competence". From 1994 until 1998, she worked as a primary teacher. From 1998 to 2004, she worked as a consultant for Causa, a consultant agency on 
educational innovation in Tilburg, The Netherlands. From 2001, she combined this job with a job as senior organisational advisor for Axxum, organisational consultancy in The Netherlands. From 2005, Anouke has worked at Fontys University for applied sciences as a program manager and since 2011 as a lecturer. Her research work focuses on teaching and teacher development in primary education.

Perry den Brok started working as a PhD student at the IVLOS Institute of Education (Utrecht University) in 1996. The title of his dissertation was "Teaching and student outcomes" (2001). From October 1999 to May 2000, he worked as a research associate at the department of Multicultural and Multilingual Education of the Graduate School of Education, George Mason University, Fairfax (Virginia), USA. From May 2003 to July 2003, he was visiting scholar at the Science and Mathematics Education Centre (SMEC), Curtin University of Technology, Perth, Australia. Between July 2001 and December 2005, he conducted a post-doctoral study at IVLOS on teaching in multicultural classrooms and was educational consultant on projects in secondary and higher education. Perry was an external research member of the research group "Teaching in Multicultural Schools" at the Academy of Teaching (Hogeschool Utrecht) between 2002 and 2006. In 2004, he entered the Dutch Educational Research School (ICO). Perry has published in several peer-reviewed journals and presented at various national and international conferences. Since September 2015, Perry has been managing director and professor at the Eindhoven School of Education. His tasks at ESoE concern the supervision of $\mathrm{PhD}$ students, coordination of the Master thesis part of the teacher training programme, and coordination of several innovation projects. His expertise lies in the domain of classroom management, teacher-student interpersonal behaviour, teaching in multicultural classes, and science learning environments research. More recently, he has started focusing on topics such as competence-based education in vocational education and training, professional development, teacher professional identity, and teacher professional careers.

\section{ORCID}

Henderijn Heldens (1) http://orcid.org/0000-0003-1894-5662

Anouke Bakx (D) http://orcid.org/0000-0003-2983-2962

Perry den Brok (D) http://orcid.org/0000-0002-4945-763X

\section{References}

Atteberry, A., \& Bryk, A. S. (2010). Centrality, connection, and commitment: The role of social networks in a school-based literacy initiative. In A. J. Daly (Ed.), Social network theory and education change (pp. 51-76). Cambridge, MA: Harvard Education Press.

Bakkenes, I., Vermunt, J. D., \& Wubbels, T. (2010). Teacher learning in the context of educational innovation: Learning activities and learning outcomes of experienced teachers. Learning and Instruction, 20, 533-548.

Blaney, N. T., Stephan, C., Rosenfield, D., Aronson, E., \& Sikes, J. (1977). Interdependence in the classroom: A field study. Journal of Educational Psychology, 69, 121-128.

Borgatti, S. P. (2006). Identifying sets of key players in a social network. Computational \& Mathematical Organization Theory, 12, 21-34.

Borgatti, S. P., \& Cross, R. (2003). A relational view of information seeking and learning in social networks. Management Science, 49, 432-445.

Borgatti, S. P., Everett, M. G., \& Freeman, L. C. (2002). UCINET for Windows: Software for social network analysis. Harvard, MA: Analytic Technologies.

Burt, R. S. (1997). The contingent value of social capital. Administrative Science Quarterly, 42, 339 365.

Burt, R. S. (2000). The network structure of social capital. Research in Organizational Behavior, 22, $345-423$.

Caena, F. (2012). Perspectives on teacher educator policies in european countries: An overview (Working document prepared for the peer learning conference Education Policy Support for Teacher Educators). Brussels, Belgium: European Commission.

Coburn, C. E., Choi, L., \& Mata, W. (2010). "I would go to her because her mind is math": Network formation in the context of a district-based mathematics reform. In A. J. Daly (Ed.), Social network theory and educational change (pp. 33-50). Cambridge, MA: Harvard Education Press. 
Coburn, C. E., \& Russell, J. L. (2008). District policy and teachers' social networks. Educational Evaluation and Policy Analysis, 30, 203-235.

Cochran-Smith, M., \& Zeichner, K. M. (Eds.). (2005). Studying teacher education: The report of the AERA Panel on Research and Teacher Education. Mahwah, NJ: Lawrence Erlbaum Associates.

Daly, A. J. (Ed.). (2010). Social network theory and educational change. Cambridge, MA: Harvard Education Press.

Daly, A. J., \& Finnigan, K. S. (2010). A bridge between worlds: Understanding network structure. Journal of Educational Change, 11, 111-138.

Darling-Hammond, L. (2010). Teacher education and the American future. Journal of Teacher Education, 61, 35-47.

De Lima, J. A. (2007). Teachers' professional development in departmentalised, loosely coupled organisations: Lessons for school improvement from a case study of two curriculum departments. School Effectiveness and School Improvement, 18, 273-301.

De Lima, J. A. (2010). Studies of networks in education: Methods for collecting and managing highquality data. In A. J. Daly (Ed.), Social network theory (pp. 243-258). Cambridge, MA: Harvard Education Press.

Deng, Z. (2007). Transforming the subject matter: Examining the intellectual roots of pedagogical content knowledge. Curricumlum Inquiry, 37, 279-295.

Doppenberg, J. J., Bakx, A. W. E. A., \& Den Brok, P. J. (2012). Collaborative teacher learning in different primary school settings. Teachers and Teaching: Theory and Practice, 18, 547-566.

Doppenberg, J. J., Den Brok, P. J., \& Bakx, A. W. E. A. (2012). Collaborative teacher learning across foci of collaboration: Perceived activities and outcomes. Teaching and Teacher Education, 28, 899-910.

Eraut, M. (2004). Informal learning in the workplace. Studies in Continuing Education, 26, 247-273.

Ferligoj, A., Doreian, P., \& Batagelj, V. (2011). Positions and roles. In J. Scott \& P. J. Carrington (Eds.), The SAGE handbook of social network analysis (pp. 434-446). London, UK: SAGE.

Finnigan, K. S., \& Daly, A. J. (2012). Mind the gap: Organizational learning and improvement in an underperforming urban system. American Journal of Education, 119, 41-71.

Frank, K. A., Zhao, Y., \& Borman, K. (2004). Social capital and the diffusion of innovations within organizations: The case of computer technology in schools. Sociology of Education, 77, 148-171.

Friend, M., \& Cook, L. (1992). Interactions: Collaboration skills for school professionals. New York, NY: Longman.

Goddard, Y. L., Goddard, R. D., \& Tschannen-Moran, M. (2007). A theoretical and empirical investigation of teacher collaboration for school improvement and student achievement in public elementary schools. Teachers College Record, 109, 877-896.

Gould, J., \& Fernandez, J. (1989). Structures of mediation: A formal approach to brokerage in transaction networks. Sociological Methodology, 19, 89-126.

Granovetter, M. S. (1982). Alienation reconsidered: The strength of weak ties. Connections, 5(2), 4 16.

Grossman, P. L., \& Richert, A. E. (1988). Unacknowledged knowledge growth: A re-examination of the effects of teacher education. Teaching and Teacher Education, 4, 53-62.

Hadar, L., \& Brody, D. (2010). From isolation to symphonic harmony: Building a professional development community among teacher educators. Teaching and Teacher Education, 26, 1641-1651.

Hanneman, R. A., \& Riddle, M. (2011). Concepts and measures for basic network analysis. In J. Scott \& P. J. Carrington (Eds.), The SAGE handbook of social network analysis (pp. 340-369). London, UK: SAGE.

HBO-raad. (2012). Een goede basis: Advies van de Commissie Kennisbasis Pabo [A good foundation: Recommendation of the Committee on Knowledge in Primary teacher education]. Den Haag, The Netherlands: Author.

Hite, J. M., Williams, E. J., \& Baugh, S. C. (2005). Multiple networks of public school administrators: An analysis of network content and structure. International Journal of Leadership in Education: Theory and Practice, 8, 91-122.

Horn, I. S., \& Little, J. W. (2010). Attending to problems of practice: Routines and resources for professional learning in teachers' workplace interactions. American Educational Research Journal, 47, 181-217.

Krackhardt, D. (1992). The strength of strong ties: The importance of philos in organizations. In N. Nohria \& R. G. Eccles (Eds.), Networks and organizations: Structure, form, and action (pp. 216239). Boston, MA: Harvard Business School Press. 
Kreijns, K., Kirschner, P. A., \& Jochems, W. (2003). Identifying the pitfalls for social interaction in computer-supported collaborative learning environments: A review of the research. Computers in Human Behavior, 19, 335-353.

Kwakman, K. (2003). Factors affecting teachers' participation in professional learning activities. Teaching and Teacher Education, 19, 149-170.

Levine, T. H., \& Marcus, A. S. (2010). How the structure and focus of teachers' collaborative activities facilitate and constrain teacher learning. Teaching and Teacher Education, 26, 389-398.

Little, J. W. (1990). The persistance of privacy: Autonomy and initiative in teachers' professional relations. Teachers College Record, 91, 509-536.

Little, J. W. (2002). Locating learning in teachers' communities of practice: Opening up problems of analysis in records of everyday work. Teaching and Teacher Education, 18, 917-946.

Little, J. W. (2003). Inside teacher community: Representations of classroom practice. Teachers College Record, 105, 913-945.

McPherson, M. Smith-Lovin, L., \& Cook, J. M. (2001). Birds of a feather: Homophily in social networks. Annual Review of Sociology, 27, 415-444.

Meirink, J. A., Imants, J., Meijer, P. C., \& Verloop, N. (2010). Teacher learning and collaboration in innovative teams. Cambridge Journal of Education, 40, 161-181. doi:10.1080/0305764X.2010. 481256

Moolenaar, N. M. (2012). A social network perspective on teacher collaboration in schools: Theory, methodology, and applications. American Journal of Education, 119, 7-39.

Moolenaar, N. M., Daly, A. J., \& Sleegers, P. J. C. (2011). Ties with potential: Social network structure and innovative climate in Dutch schools. Teachers College Record, 113, 1983-2017.

Moolenaar, N. M., Sleegers, P. J. C., Karsten, S., \& Daly, A. J. (2012). The social fabric of elementary schools: A network typology of social interaction among teachers. Educational Studies, 38, 355371.

Mostert, M. P. (1998). Interprofessional collaboration in schools. Boston, MA: Allyn and Bacon.

Penuel, W. R., Frank, K. A., \& Krause, A. (2010). Between leaders and teachers. Using social network analysis to examine the effects of distributed leadership. In A. J. Daly (Ed.), Social network theory and educational change (pp. 159-178). Cambridge, MA: Harvard Education Press.

Penuel, W. R., Riel, M., Krause, A. E., \& Frank, K. A. (2009). Analyzing teachers' professional interactions in a school as social capital: A social network approach. Teachers College Record, 111, $124-163$.

Porter, A., McMaken, J., Hwang, J., \& Yang, R. (2011). Common Core standards: The new U.S. intended curriculum. Educational Researcher, 40, 103-116. doi:10.3102?0013189X11405038

Programmaraad Verbreding Techniek Basisonderwijs. (2004). Bouwen aan een brede basis: Nationaal actieplan verbreding techniek basisonderwijs 2004-2010 [Building a broad base: National action plan broadening technology in primary education 2004-2010]. Den Haag, The Netherlands: Author.

Rosenholtz, S. J. (1989). Teachers' workplace: The social organization of schools. New York, NY: Longman.

Scott, J., \& Carrington, P. J. (Eds.). (2011). The SAGE handbook of social network analysis. London, UK: SAGE.

Shank, M. J. (2006). Teacher storytelling: A means for creating and learning within a collaborative space. Teaching and Teacher Education, 22, 711-721.

Shulman, L. S. (1986). Those who understand: Knowledge growth in teaching. Educational Researcher, 15(2), 4-14.

Siskin, L. S. (1994). Realms of knowledge: Academic departments in secondary schools. Washington, DC: Falmer Press.

Spillane, J. P. (2005). Distributed leadership. The Educational Forum, 69, 143-150.

Spillane, J. P., Halverson, R., \& Diamond, J. B. (2004). Towards a theory of leadership practice: A distributed perspective. Journal of Curriculum Studies, 36, 3-34.

Stodolsky, S. S., \& Grossman, P. L. (1995). The impact of subject matter on curricular activity: An analysis of five academic subjects. American Educational Research Journal, 32, 227-249.

Tynjälä, P. (2008). Perspectives into learning at the workplace. Educational Research Review, $3,130-154$.

Van Wessum, L. (1997). De sectie als eenheid: Samenwerking en professionaliteitsopvattingen van docenten in het voortgezet onderwijs [The department as a unit: Collaboration and teachers' 
views on professionalism in secondary education]. Utrecht, The Netherlands: Department of Educational Sciences/ISOR/Utrecht University.

Vogt, W. P. (1993). Dictionary of statistics and methodology: A nontechnical guide for the social sciences. Newbury Park, CA: SAGE.

Wenger, E. (1998). Communities of practice: Learning, meaning, and identity. New York, NY: Cambridge University Press.

Westheimer, J. (2008). Learning among colleagues: Teacher community and the shared enterprise of education. In M. Cochran-Smit, S. Feiman-Nemser, \& D. J. McIntyre (Eds.), Handbook of research on teacher education: Enduring questions in changing contexts (3rd ed., pp. 756783). New York, NY: Routledge.

Witterholt, M., Goedhart, M., \& Suhre, C. (2015). The impact of peer collaboration on teachers' practical knowledge. European Journal of Teacher Education. Advance online publication. doi:10. 1080/02619768.2015.1109624

Witziers, B., Sleegers, P., \& Imants, J. (1999). Departments as teams: Functioning, variations and alternatives. School Leadership \& Management, 19, 293-304. 